\title{
Determination of Optimal Levels of Energy, Protein, and Fiber in the Diets of New Zealand White Growing Rabbits Based on Nutrient-Response Models
}

\section{Nguyen Xuan Trach ${ }^{1}$, Tran Hiep ${ }^{1}$, Nguyen Thi Duong Huyen ${ }^{1}$ \& Nguyen Van Dat ${ }^{2}$}

${ }^{1}$ Faculty of Animal Science, Vietnam National University of Agriculture, Hanoi 131000, Vietnam

${ }^{2}$ Faculty of Agriculture, Vinh Phuc Technology - Economics College, Vinh Phuc 280000, Vietnam

\begin{abstract}
A study was conducted to estimate the optimal levels of energy, protein, and fiber in the diets of New Zealand White (NZW) growing rabbits fed on fresh green forage available in North Vietnam. Mathematical modelling of nutrient-response curves was applied for the study. A total of 125 male growing rabbits at 6 weeks of age were randomly divided into 25 groups of 5 each to be fed on diets with an array of different levels of metabolizable energy (ME), crude protein $(\mathrm{CP})$, and acid detergent fiber (ADF) by means of varying the ratio between fiber rich grasses, viz. elephant grass (Pennisetum purpureum), Setaria grass (Setaria sphacelata), or Para grass (Brachiaria mutica), and protein rich forages, viz. water spinach (Ipomoea aquatica) vines, sweet potato (Ipomoea batatas) vines, or Trichantera leaves (Trichanthera gigantea), in the basal diets. The average daily gain (ADG) and feed conversion ratio (FCR) were used as key responses of the rabbits to varied levels of $\mathrm{ME}, \mathrm{CP}$, and ADF in the diets. The results showed that the levels of $\mathrm{ME}, \mathrm{CP}$, and ADF in the diets strongly affected the ADG and FCR of the rabbits following curvilinear patterns with the highest ADG and lowest FCR when the diet contained 2106-2162 Kcal ME kg-1 DM with 16.5-16.8\% CP and 21.9-22.4\% ADF. Therefore, these levels of nutrients were considered to be optimal in the diets of NZW growing rabbits fed on local forages.
\end{abstract}

Received: January 9, 2019 Accepted: May 7, 2019

Correspondence to nxtrach@vnua.edu.vn

ORCID

Nguyen Xuan Trach https://orcid.org/0000-0001-67681590

\section{Keywords}

Nutrient-Response Model, Rabbits, Energy, Protein, Fiber

\section{Introduction}

In developed countries, rabbits are normally fed high starchbased diets (Xiccato et al., 2011). Starch is the main source of energy for feeding rabbits, however, high-starch low-fiber diets 
have been considered responsible for digestive troubles for a long time (Blas \& Gidenne, 2010; De Blas \& Mateos, 2010). In addition, a high dietary protein level, besides affecting growth performance and nitrogen excretion of rabbits (Xiccato \& Trocino, 2010), may impair caecal fermentation and alter gut microflora composition, and thus is considered to be among the causes of increased mortality in rabbits (De Blas et al., 1999; Carabaño et al., 2009). Otherwise, the substitution of starch with soluble fiber has been shown to often reduce mortality (Gidenne \& Perez, 2000; Soler et al., 2004; Xiccato et al., 2008). Moreover, the starch-based and high protein diets used in developed countries are mainly due to high labor costs; but these diets may remove the significant advantage of rabbits as herbivores (Leng, 2008). Therefore, the development of efficient rabbit diets should be based on locally available forages of high nutritive value in developing countries.

In fact, feeding exotic rabbits on locally available forages has recently been very popular in Vietnam. Several studies in the country have revealed that feeding rabbits with local feeds can maintain their high growth rate and efficient feed conversion (Luyen \& Preston, 2012). Tam et al. (2009) and Huyen et al. (2013a, 2013b) found that the average daily gain (ADG) was improved and the feed conversion ratio (FCR) reduced when New Zealand White (NZW) rabbits were fed a protein-rich forage-based diet (water spinach or sweet potato vines) supplemented with energy and/or fiber-rich feeds (paddy rice, broken rice, or broken rice with added rice husks). Similarly, Hang et al. (2013) found linear increases in the growth rate of NZW growing rabbits when forage-based diets were supplemented with paddy rice up to $20 \mathrm{~g} / \mathrm{head} /$ day. However, these studies only focused on the levels of replacement and/or supplementation of different local feeds but did not provide any information on the optimal levels of nutrients in the diet. It is clear that knowledge of nutrient requirements or nutrient levels in a diet based on local forages of rabbits in general, and NZW rabbits in particular, is still limited. Therefore, there is a high need for research to determine the optimal levels of nutrients in the diets of exotic rabbits fed on forages available in the country. The present paper reports an experiment to estimate optimal levels of metabolizable energy (ME), crude protein $(\mathrm{CP})$, and acid detergent fiber (ADF) in the diets of NZW growing rabbits based on feed resources available in North Vietnam using the method of mathematically modelling nutrientresponse curves.

\section{Materials and Methods}

\section{Animals and diets}

A total of 125 male NZW growing rabbits at 6 weeks of age were randomly allocated into 25 groups of 5 each to be fed on different diets based on fiber-rich grasses (Elephant grass, Setaria grass, or Para grass) mixed with proteinrich forages (water spinach vine, sweet potato vine, or Trichantera leaves) (Table 1) at varied proportions $(0,25,50,75$, and $100 \%)$ to make a large array of ME, CP, and ADF levels (Table 2). In addition to the green fodder, the rabbits were supplemented with paddy rice at $2 \%$ of their body weight (BW). The levels of $\mathrm{ME}, \mathrm{CP}$, and $\mathrm{ADF}$ in the diets varied in large ranges (Table 3) that covered all the spectra of respective values of the nutrients in the diet recommended for rabbits by NRC (1977), Lebas (1980), and other studies (Tao \& Li, 2006; De Blas \& Wiseman, 2010; Halls, 2010; Osho et al., 2013).

\section{Feeding management}

The experiment was carried out at the experimental animal farm of Vietnam National University of Agriculture for 8 weeks after a period of 7 days of adaptation. Before the experiment began, the rabbits were vaccinated against hemorrhagic disease using the VHD vaccine and drenched against coccidiosis using an ANTICOC product. At each time of feeding, feeds were chopped and mixed according to the designed proportions. Rabbits were fed green fodder three times a day at 8:00, 14:00, and 20:00. Paddy rice was fed at 11:00 am every day. Water was made available at all times. 
Table 1. Chemical composition and metabolizable energy values of the experimental feeds

\begin{tabular}{|c|c|c|c|c|c|c|c|c|}
\hline Feed & $\begin{array}{l}\mathrm{DM} \\
(\%)\end{array}$ & $\begin{array}{c}\mathrm{CP} \\
(\% \mathrm{DM})\end{array}$ & $\begin{array}{c}\text { NDF } \\
(\% \mathrm{DM})\end{array}$ & $\begin{array}{c}\text { ADF } \\
(\% \text { DM) }\end{array}$ & $\begin{array}{c}\mathrm{CF} \\
(\% \mathrm{DM})\end{array}$ & $\begin{array}{c}\text { EE } \\
(\% \text { DM) }\end{array}$ & $\begin{array}{c}\text { Ash } \\
(\% \text { DM) }\end{array}$ & $\begin{array}{c}\text { ME } \\
(\text { Kcal kg-1 DM) }\end{array}$ \\
\hline Elephant grass & 14.43 & 14.44 & 62.36 & 33.14 & 28.89 & 0.62 & 13.42 & 1827 \\
\hline Setaria grass & 13.67 & 15.29 & 60.38 & 33.21 & 28.87 & 2.86 & 11.03 & 1990 \\
\hline Para grass & 17.17 & 11.26 & 76.39 & 35.35 & 31.40 & 0.59 & 11.42 & 1875 \\
\hline Water spinach vine & 11.82 & 26.79 & 30.07 & 19.72 & 20.42 & 1.32 & 11.95 & 2445 \\
\hline Sweet potato vine & 11.00 & 23.06 & 37.76 & 22.45 & 19.78 & 2.55 & 11.24 & 2398 \\
\hline Trichantera leaves & 17.45 & 18.82 & 45.76 & 25.46 & 24.41 & 2.27 & 14.27 & 2058 \\
\hline Paddy rice & 88.01 & 6.94 & 32.19 & 16.60 & 13.86 & 0.29 & 8.10 & 2819 \\
\hline
\end{tabular}

Table 2. Design of the experimental diets

\begin{tabular}{llllc}
\hline PAR100 \& TRI0 & ELE100 \& WAS0 & SET100 \& SWP0 & WAS \& THOC0 & SWP \& RICE0 \\
PAR75 \& TRI25 & ELE75 \& WAS25 & SET75 \& SWP25 & WAS \& THOC1 & SWP \& RICE1 \\
PAR50 \& TRI50 & ELE50 \& WAS50 & SET50 \& SWP50 & WAS \& THOC2 & SWP \& RICE2 \\
PAR25 \& TRI75 & ELE25 \& WAS75 & SET25 \& SWP75 & WAS \& THOC3 & SWP \& RICE3 \\
PAR0 \& TRI100 & ELE0 \& WAS100 & SET0 \& SWP100 & WAS \& THOC4 & SWP \& RICE4 \\
\hline
\end{tabular}

Note: $0,25,50,75$, and 100 are the levels of fresh green forage in the diet; $0,1,2,3$, and 4 are the levels of paddy rice (\% BW). PAR - Para grass, TRI - Trichantera leaves, ELE - elephant grass, WAS - water spinach, SWP - sweet potato vines, SET - Setaria grass, and RICE - paddy rice.

Table 3. Variation in the nutrient contents of the experimental diets

\begin{tabular}{lccccc}
\hline \multicolumn{1}{r}{ Nutrients } & $\mathrm{n}$ & Mean & SD & Cv\% & Range \\
\hline Energy, Mcal ME $\mathrm{kg}^{-1}$ DM & 25 & $2.251 \pm 0.276$ & 0.269 & 11.73 & $1.905 \div 2.982$ \\
Protein, \% DM & 25 & $15.94 \pm 3.98$ & 4.81 & 29.42 & $10.39 \div 26.51$ \\
ADF, \% DM & 25 & $26.17 \pm 4.58$ & 4.69 & 18.57 & $13.16 \div 31.60$ \\
\hline
\end{tabular}

\section{Data collection}

All animals were individually weighed at the beginning of the experiment and thereafter once a week at 7:00 am before the morning feeding. The ADG was calculated by means of the slope of the linear regression of the weekly live weights on the experimental time.

During the experimental period, the offered feeds were weighed before each meal and the refusals were collected and weighed each morning before the first meal every day. Samples of the offered feeds and refusals were collected and dried at $105^{\circ} \mathrm{C}$ until a constant weight to determine dry matter and then ground through a 1mm screening mesh (Cyclotec 1093 sample mill, Foss, Hillerød, Denmark). After a week, all daily feed and refusal samples were mixed (for each batch of feed offered and for refusals of each individual rabbit) for later analysis of chemical composition.

In the middle of the experiment, total feed intake and feces of each rabbit were collected over a period of 7 consecutive days. Representative fecal samples (10\%) were taken daily from the total collected feces and stored at $-25^{\circ} \mathrm{C}$. On the last day of the collection period, the samples were bulked for each individual rabbit.

The samples of feeds and refusals, as well as fecal samples, were analyzed for dry matter, organic matter, ash, crude protein, and fat according to AOAC (1990). Neutral detergent 
fiber (NDF) and ADF were determined following the procedures of Van Soest et al. (1991). ME was estimated based on chemical composition using the formulae of Lebas (2013).

Feed intake was calculated by the difference between the amount of feed offered and refusals on a dry matter (DM) basis. Digestibility (\%) was calculated as $(\mathrm{A}-\mathrm{B} / \mathrm{A}) * 100$; where $\mathrm{A}$ and $\mathrm{B}$ are the total nutrient intake and total nutrient in the feces, respectively. The FCR was calculated as a ratio of DM intake per live weight gain.

\section{Statistical analysis}

In order to describe the nutrient-response curves, the generalized least squares model was applied to find the regression equations which best showed the responses of the rabbits (ADG and FCR) as dependent variables to the levels of diet nutrients (ME, CP, and $\mathrm{ADF}$ ) as independent variables. After that, solver analysis was used to calculate the optimal levels of $\mathrm{ME}, \mathrm{CP}$, and ADF in the diet based on the following principles (Mercer, 1992; Vedenov \& Pesti, 2008; Tedeschi et al., 2010): (1) The optimal level of the nutrient input is the level that gives the maximal output level, which was applied for the ADG; and (2) The optimal level of the nutrient input is the lowest level calculated for each unit of output, which was applied for the FCR.

\section{Results and Discussion}

Table 3 and Figures 1-3 show the parameters and patterns of regression of the ADG and FCR of the rabbits on the levels of $\mathrm{ME}, \mathrm{CP}$, and ADF in their diet. It can be seen that the level of ME in the diet had a significant influence on the ADG and FCR following the quadratic equations. The accuracy of the regression equation was "high" for the ADG and "acceptable" for the FCR. The ADG gradually increased with increasing levels of ME up to $2162 \mathrm{Kcal} \mathrm{kg}^{-1} \mathrm{DM}$, then decreased afterwards. In contrast, the FCR gradually decreased with increasing ME up to $2106 \mathrm{Kcal}$ $\mathrm{kg}^{-1} \mathrm{DM}$, then increased. Combining the two curves, it can be seen that an energy level from

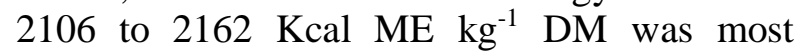
suitable for the NZW growing rabbits.

The level of $\mathrm{CP}$ in the diet significantly affected the ADG and FCR following the quadratic functions with an "average" accuracy for both equations. The ADG tended to increase with increased CP up to $15 \%$, and remained steady with $15-17 \%$ CP. With higher levels of $\mathrm{CP}$, the ADG tended to decrease. Solver analysis found that the best $\mathrm{CP}$ level in the diet was $16.52 \%$ for the ADG. The FCR followed a reversed quadratic manner with the lowest value when the CP was $16.75 \%$. So, with these two concerns, NZW growing rabbits best responded to diets with $16.50-16.75 \% \mathrm{CP}$ on a DM basis.

Table 3. Regressions of the ADG and FCR of rabbits on the levels of ME, CP, and ADF in their diet

\begin{tabular}{|c|c|c|c|c|}
\hline Regression equation & MPE & RPE & $\mathrm{R}^{2}$ & $\mathrm{R}^{2} \mathrm{adj}$ \\
\hline \multicolumn{5}{|l|}{ Level of ME, Kcal kg-1 DM } \\
\hline (1) $\mathrm{ADG}=-73.00+0.08648 \mathrm{ME}-0.000020 \mathrm{ME}^{2}$ & 1.44 & 7.10 & 77.10 & 76.50 \\
\hline (2) FCR $=33.24-0.02528 \mathrm{ME}+0.000006 \mathrm{ME}^{2}$ & 0.60 & 11.01 & 52.30 & 51.06 \\
\hline \multicolumn{5}{|l|}{ Level of $C P, \% D M$} \\
\hline (3) $\mathrm{ADG}=2.538+2.153 \mathrm{CP}-0.06518 \mathrm{CP} \mathrm{P}^{2}$ & 2.80 & 13.82 & 69.90 & 69.20 \\
\hline (4) $\mathrm{FCR}=11.78-0.7912 \mathrm{CP}+0.02361 \mathrm{CP}^{2}$ & 0.67 & 12.38 & 50.80 & 49.90 \\
\hline \multicolumn{5}{|l|}{ Level of ADF, \% DM } \\
\hline (5) $\mathrm{ADG}=-23.99+4.12 \mathrm{ADF}-0.0919 \mathrm{ADF}^{2}$ & 1.30 & 6.43 & 83.00 & 82.60 \\
\hline (6) $\mathrm{FCR}=16.58-1.076 \mathrm{ADF}+0.02461 \mathrm{ADF}^{2}$ & 0.58 & 10.74 & 51.90 & 50.90 \\
\hline
\end{tabular}

Note: MPE: Mean prediction error, RPE: Relative prediction error, $R^{2}$ : Coefficient of determination, $R^{2}$ adj: Adjusted coefficient of determination. 

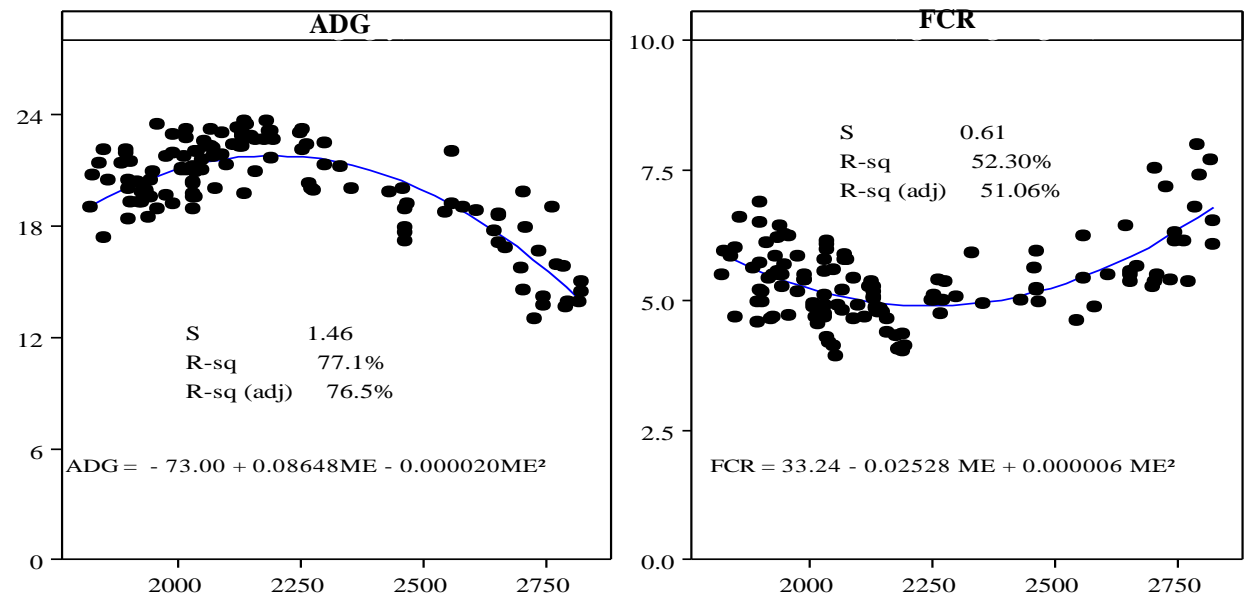

Level of ME in the diet (Kcal $\left.\mathrm{g}^{-1} \mathrm{DM}\right)$

Figure 1. Response curves (ADG and FCR) of rabbits for the levels of ME in their diet
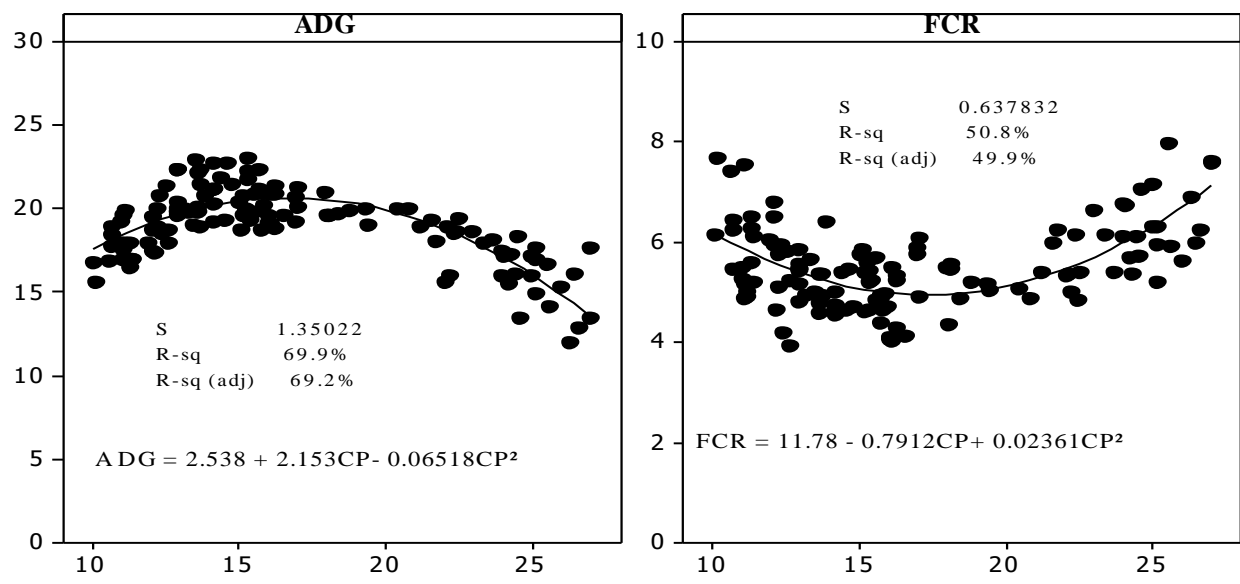

Level of CP in the diet (\% DM)

Figure 2. Response curves ( $A D G$ and FCR) of rabbits for the levels of $C P$ in their diet
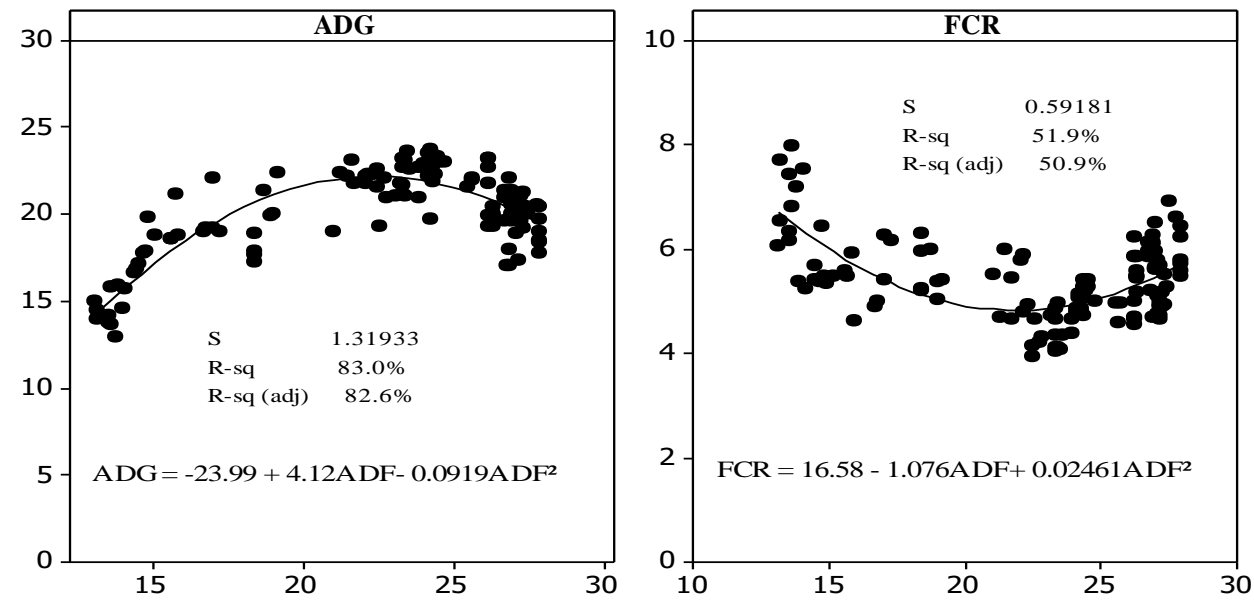

Level of ADF in the diet (\% DM)

Figure 3. Response curves ( $A D G$ and FCR) of rabbits for the levels of ADF in their diet 
Both the ADG and FCR were also influenced by the level of ADF in the diet following quadratic manners with a "high" accuracy for the ADG and an "average" accuracy for the FCR. The ADG of the rabbit gradually increased and the FCR gradually decreased when the ADF was increased up to 22-23\% DM, then a reversal trend happened. Solver analysis found that the ADG was highest when the diet contained $22.4 \% \mathrm{ADF}$ and the FCR was lowest when the ADF was $21.86 \%$.

The recommended level of energy for NZW growing rabbits is variable in the literature. Ali et al. (2011) showed that NZW male rabbits reached an ADG from 27.11 to $29.63 \mathrm{~g} \mathrm{day}^{-1}$ when they were fed a diet with $2055 \mathrm{Kcal} \mathrm{ME}$ $\mathrm{kg}^{-1}$ DM. Obinne \& Okorie (2008) stated that a diet with $9.7 \mathrm{Mj} \mathrm{DE} \mathrm{kg}^{-1} \mathrm{DM}(1901 \mathrm{Kcal} \mathrm{ME}$ $\mathrm{kg}^{-1} \mathrm{DM}$ ) could ensure the growth of rabbits in the tropics. However, according to Obinne \& Mmereole (2010), the ADG of NZW rabbits was highest when the diet contained $10.8 \mathrm{Mj} \mathrm{DE}$ (2116 Kcal ME). On the other hand, Wang et al. (2012) saw that the suitable level of energy for NZW rabbits at 4-11 weeks of age was $11.7 \mathrm{Mj}$ DE (2293 Kcal ME). NRC (1977) and Lebas \& Gidenne (2000) recommended that the suitable energy level for rabbits was 2050 and $2187 \mathrm{Kcal}$ ME $\mathrm{kg}^{-1} \mathrm{DM}$, respectively. According to the nutrient-response curves in our present study, the optimal level of energy (2106-2162 Kcal ME $\left.\mathrm{kg}^{-1} \mathrm{DM}\right)$ is in agreement with those recommended by NRC (1977), Lebas \& Gidenne (2000), and Obinne \& Mmereole (2010). This confirms the applicability of the method of mathematically modelling nutrientresponse curves as a convenient way for the determination of nutrient requirements of rabbits.

The quadratic patterns of response of the ADG and FCR to CP may be due to the idea that at the beginning of the experiment the protein requirement was better met when $\mathrm{CP}$ was increased up to $16.75 \%$, but not thereafter when the supply was more than needed by the animals. Dong et al. (2006) also found that the replacement of para grass, which has a low protein level $(12.9 \%)$, in the basal diet with water spinach, which has a high protein level
(26.3\% CP), clearly increased the ADG of crossbred rabbits. Luyen \& Preston (2012) reported that sweet potato vines and paddy rice supported higher growth rates and better feed conversion than guinea grass (Panicum maximum) plus concentrates. This was probably due to the higher protein contents of the sweet potato vines and paddy rice feeding system $(16.8-23.8 \% \mathrm{CP})$ compared with guinea grass plus concentrates system $(11.5-14.3 \% \mathrm{CP})$. The authors also reported the best ADG $\left(20.1 \mathrm{~g} \mathrm{~d}^{-1}\right)$ was obtained from a diet containing $60 \%$ sweet potato vines and $40 \%$ paddy rice $(16.8 \% \mathrm{CP})$. Chat et al. (2005), who replaced guinea grass (low CP) with water spinach (high CP), found similar responses. However, having a too high a protein level was not necessary because the rabbits had to eliminate the excessive nitrogen from their bodies with some cost of energy when their protein requirement was already met. This may be the reason why in the present study the ADG tended to decrease when the level of $\mathrm{CP}$ in the diet was too high $(>16.75 \%)$.

Ali et al. (2011), Obinne \& Okorie (2008), and Obinne \& Mmereole (2010) state that growth performance was at the highest rate when rabbits were fed diets with a CP content of $16 \%, 16 \%$, and $16.2 \%$, respectively. Similarly, Wang et al. (2012) concluded that the suitable content of CP for NZW rabbits at 4-11 weeks of age was $16 \%$. The best CP level according to the present nutrient-response models (16.52$16.75 \% \mathrm{CP}$ ) seemed to be a little bit higher than the findings of the mentioned authors. This might be related to the lower quality of the tropical feeds used.

De Blas et al. (1999), Leng (2008), and De Blas \& Wiseman (2010) state that fiber plays an important role in balancing the activities of microorganisms in the rabbit digestive system, maintaining intestine peristalsis, and thus helping to maintain a healthy digestive system. Moreover, fiber is a prominent resource of energy for microorganisms in the large intestine. If a diet is short in fiber, it would lead to a decrease in intestine peristalsis and it would take a longer time to circulate feed in the digestive system (Irlbeck, 2001). Nevertheless, having a too high level of fiber would lead to a 
decrease in the digestion rate and activities of the microorganisms, which should cause a reduction in feed intake, ME, and other available nutrients in the diet. This would cause reduced productivity of the rabbit (Tao \& $\mathrm{Li}$, 2006; Osho et al., 2013). Luyen \& Preston (2012) found the best ADG when rabbits were fed a diet containing 60-70\% sweet potato vines and $30-40 \%$ paddy rice, that contained 20.8$21.9 \%$ ADF. According to Pinheiro et al. (2009), the best level of ADF for rabbit growth was $23.3 \%$. Osho et al. (2013) concluded that rabbits could reach a good growth rate when the diet contained 18.8-25.2\% ADF. So, the best responses of rabbits to the level of ADF in the present models (21.86-22.42\% ADF) are in accordance with their findings.

Based on the present nutrient-response models, the optimal levels of ME, CP, and ADF may be suggested for NZW growing rabbits fed on local forages to obtain the highest ADG and lowest FCR. However, the regression analyses were only made separately for each independent variable (nutrient) with an assumption that there was no interaction among them. Another important issue is that, so far, there have been few measurements of true ME in rabbits and most values are based on equations derived from other species. In the present study, the ME values of the diets were calculated based on such equations, so the results might be misleading, as they did not take into account the nature of the fiber component and specific digestive physiology of the rabbit (Leng, 2008). Thus, combinations of cereal-based concentrates and grasses may be less efficiently used than a diet based on highly digestible foliage such as sweet potato foliage or water spinach (Luyen \& Preston, 2012). Furthermore, nutritional optima for the best animal performance are not necessarily economic optima as these levels will depend on the relative costs of the feed ingredients. To maximize profits, it is necessary to optimize, but not necessarily maximize, animal productivity.

\section{Conclusions}

The method of mathematically modelling nutrient-response curves can be conveniently applied to estimate the optimal levels of $\mathrm{ME}, \mathrm{CP}$, and $\mathrm{ADF}$ in the diets of NZW growing rabbits. It can, therefore, be preliminarily concluded from the present study that the best diet for NZW growing rabbits fed on available forages in the North of Vietnam contains 2106-2162 Kcal ME $\mathrm{kg}^{-1} \mathrm{DM}, 16.5-16.8 \% \mathrm{CP}$, and 21.9-22.4\% ADF. However, there is still a need for further research to confirm these findings, especially, when the interactions among the diet components are taken into account. In addition, the economic response should also be considered to ensure economic optima of practical diets.

\section{Acknowledgments}

The authors are very grateful to the Swedish International Development Cooperation Agency, Department for Research Cooperation (Sida-SAREC), through the regional MEKARN Project, for the financial support of this study.

\section{References}

Ali F., Omer H., Abedo A., Abdel-Magid S. S. \& Ibrahim S. A. (2011). Using mixture of sweet basal and black cumin as feed additives with different levels of energy in growing rabbit diets. American-Eurasian Journal of Agricultural and Environmental Sciences. 10(5): 917-927.

AOAC (1990). Official methods of analysis of the Association of Official Analytical Chemists.

Blas E. \& Gidenne T. (2010). Digestion of starch and sugars. In: De Blas C. \& Wiseman J. (2010). Nutrition of the Rabbit ( $2^{\text {nd }}$ ed.). CABI Publishing, Wallingford, UK.

Carabaño R., Villamide M. J., García J., Nicodemus N., Llorente A., Chamorro S., Menoyo D., Garc1'aRebollar P., Garcı'a-Ruiz A. I. \& De Blas J. C. (2009). New concepts and objectives for proteinamino acid nutrition in rabbits: a review. World Rabbit Science. 17: 1-14.

Chat T. H., Dung N. T., Van Binh D. \& Preston T. (2005). Water spinach (Ipomoea aquatica) as replacement for guinea grass for growing and lactating rabbits. Livestock Research for Rural Development. 17(10): Article 109.

De Blas C., García J. \& Carabaño R. (1999). Role of fibre in rabbit diets. A review. Annales de Zootechnie. 48(1): 3-13. 
De Blas C. \& Wiseman J. (2010). Nutrition of the Rabbit ( $2^{\text {nd }}$ ed.). CABI Publishing, Wallingford, UK.

De Blas J. C. \& Mateos G. G. (2010). Feed formulation. In: De Blas C. \& Wiseman J. (Eds.). The Nutrition of the Rabbit ( $2^{\text {nd }}$ ed.). CABI Publishing, Wallingford, UK.

Dong N. T. K., Van Thu N. \& Preston T. (2006). Effect of dietary protein supply on the reproductive performance of crossbred rabbits. Paper presented at the MEKARN workshop on forages for pigs and rabbits, Phnom Penh, Cambodia.

Gidenne T. \& Perez J. M. (2000). Replacement of digestible fibre by starch in the diet of the growing rabbit. I. Effects on digestion, rate of passage and retention of nutrients. Annales de Zootechnie. 49: 357-368.

Halls A. E. (2010). Nutritional Requirements for Rabbits. Shur-Gain, Nutreco Canada Inc.

Hang B. P. T., Lam V. \& Preston T. (2013). Effect of paddy rice on growth performance of rabbits fed water spinach as the sole forage or combined with leaves of water hyacinth. Livestock Research for Rural Development. 25(3): Article 45.

Huyen N. T. D., Trach N. X. \& Preston T. (2013a). Effects of paddy rice on feed utilization and growth of New Zealand White rabbits fed basal diets of water spinach (Ipomoea aquatica) or sweet potato vines (Ipomoea batatas). Livestock Research for Rural Development. 25(6): Article 100.

Huyen N. T. D., Trach N. X. \& Preston T. (2013b). Effects of supplementation of paddy rice and/or rice grain and/or rice husk to sweet potato (Ipomoea batatas) vines as basal diet on growth performance and diet digestibility in rabbits. Livestock Research for Rural Development. 25(1): Article 19.

Irlbeck N. (2001). How to feed the rabbit (Oryctolagus cuniculus) gastrointestinal tract. Journal of Animal Science. 79(E-Suppl): 343-346.

Lebas F. (1980). Research on rabbit feeding: Evolution over the last 20 years and prospect for the future. Retrieved from https://www.researchgate.net/publication/27173623 3_Les_recherches_sur_1\%27Alimentation_du_lapin _Evolution_au_cours_des_20_dernieres_annees_et_ persepectives_d\%27avenir on January 28, 2019 (in French)

Lebas F. (2013). Feeding strategy for small and medium scale rabbit units. Paper presented at the 3rd Conference of Asian Rabbit Production Association, Bali, Indonesia.

Lebas F. \& Gidenne T. (2000). Recent research advances in rabbit nutrition. Retrieved from https://www.researchgate.net/publication/2680035_ RECENT_RESEARCH_ADVANCES_IN_RABBIT _NUTRITION on January 28, 2019.
Leng R. A. (2008). Digestion in the rabbit - a new look at the effects of their feeding and digestive strategies. Paper presented at the MEKARN Rabbit Conference on organic rabbit production from forages, Can Tho University, Vietnam.

Luyen L. T. \& Preston T. (2012). Growth performance of New Zealand White rabbits fed sweet potato (Ipomoea batatas) vines supplemented with paddy rice or Guinea grass supplemented with commercial concentrate. Livestock Research for Rural Development. 24(7): Article 127.

Mercer L. P. (1992). The determination of nutritional requirements: Mathematical modeling of nutrientresponse curves. The Journal of Nutrition. 122(Suppl. 3): 706-708.

NRC (1977). Nutrient Requirements of Rabbits ( $2^{\text {nd }}$ ed.). The National Academies Press. Washington, DC.

Obinne J. \& Mmereole F. (2010). Effects of different dietary crude protein and energy levels on production performance, carcass characteristics and organ weights of rabbits raised under the humid environment of Nigeria. Agricultura Tropica et Subtropica. 43: 4-10.

Obinne J. \& Okorie A. (2008). Effect of different crude protein and digestible energy levels on the growth performance of rabbits in the tropics. Nigerian Journal of Animal Production. 35: 210-216.

Osho S. O., Oso A. O., Akpan I. E., Ayanniyi T. A., Fafiolu A. O., Jegede A. V., Isah O. A., Aderinboye R. Y., Dele P., Ojo V. O. A., Ogunade I. M., Durosaro S. O., Ekunseitan D. A., Ayoola A. A. \& Idowu O. M. O. (2013). Effect of varying NDF, ADF and digestible energy levels on growth performance, nutrient digestibility, caecal fermentation, caecal and faecal microflora of growing rabbits. Global Journals. 13(1): 5-13.

Pinheiro V., Guedes C., Outor-Monteiro D. \& Mourão J. L. (2009). Effects of fibre level and dietary mannanoligosaccharides on digestibility, caecal volatile fatty acids and performances of growing rabbits. Animal Feed Science and Technology. 148(2-4): 288-300.

Soler M. D., Blas E., Cano J. L., Pascual J. J., Cervera C. \& Fernández-Carmona J. (2004). Effect of digestible fibre/starch ratio and animal fat level in diets around weaning on mortality rate of rabbits. In Proceedings of the $8^{\text {th }}$ World Rabbit Congress, Puebla, Mexico: 996-1001.

Tam N. H., Tuan V. T., Lam V., Hang B. P. T. \& Preston T. (2009). Effects on growth of rabbits of supplementing a basal diet of water spinach (Ipomoea aquatica) with vegetable wastes and paddy rice. Livestock Research for Rural Development. 21(10): Article 174.

Tao Z. \& Li F. (2006). Effects of dietary neutral detergent fibre on production performance, nutrient utilization, 
caecum fermentation and fibrolytic activity in 2 to 3 month-old New Zealand rabbits. Journal of Animal Physiology and Animal Nutrition. 90(11-12): 467473.

Tedeschi L. O., Cannas A. \& Fox D. G. (2010). A nutrition mathematical model to account for dietary supply and requirements of energy and other nutrients for domesticated small ruminants: The development and evaluation of the Small Ruminant Nutrition System. Small Ruminant Research. 89(2-3): 174-184.

Van Soest P. J., Robertson J. B. \& Lewis B. A. (1991). Methods for dietary fiber, neutral detergent fiber, and nonstarch polysaccharides in relation to animal nutrition. Journal of Dairy Science. 74(10): 35833597.

Vedenov D. \& Pesti G. M. (2008). A comparison of methods of fitting several models to nutritional response data. Journal of Animal Science. 86(2): 500-507.

Xiccato G. \& Trocino A. (2010). Energy and protein metabolism and requirements. In: De Blas C. \& Wiseman J. (Eds.). Nutrition of the Rabbit ( $2^{\text {nd }}$ ed.). CABI Publishing, Wallingford, UK.

Xiccato G., Trocino A., Carraro L., Fragkiadakis M. \& Majolini D. (2008). Digestible fibre to starch ratio and antibiotic treatment time in growing rabbits affected by epizootic rabbit enteropathy. In Proceedings of the $9^{\text {th }}$ World Rabbit Congress, Verona, Italy: 847-851.

Xiccato G., Trocino A., Majolini D., Fragkiadakis M. \& Tazzoli M. (2011). Effect of decreasing dietary protein level and replacing starch with soluble fibre on digestive physiology and performance of growing rabbits. Animal. 5(8): 1179-1187.

Wang X., Ma M., Sun L., Wang C., Zhu Y. \& Li F. (2012). Effects of different protein, fibre and energy levels on growth performance and the development of digestive organs in growing meat rabbit. Paper presented at the $10^{\text {th }}$ World Rabbit Congress. 